Acta vet. scand. $1986,27,243-249$.

From the Department of Pharmacology and Toxicology, Norwegian College of Veterinary Medicine, Oslo, Norway.

\title{
PHARMACOKINETICS OF SULFAPHENAZOLE IN SHEEP
}

\author{
By \\ Stig Anders Ødegaard
}

\begin{abstract}
ØDEGAARD, STIG ANDERS: Pharmacokinetics of sulfaphenazole in sheep. Acta vet. scand. 1986, 27, 243-249. - Proprietary formulations of sulfaphenazole were administered intravenously and orally to sheep. After intravenous injection the disposition of sulfaphenazole was described by an open two compartment model, and the elimination half-time was on average $5.58 \mathrm{~h}$. The apparent volume of distribution was $0.273 \mathrm{l} / \mathrm{kg}$ and total body clearance $34.1 \mathrm{ml} / \mathrm{kg} / \mathrm{h}$. Judged from the area under the curves, the oral dose was completely absorbed. Drug plasma concentrations versus time fitted an open one compartment model, the half-time of absorption and elimination being 2.66 and $7.12 \mathrm{~h}$, respectively. The binding to plasma proteins was high i.e. 93-96 \% at therapeutic concentrations, and concentration dependent. The results demonstrate that the doses indicated by the manufacturer appear to be low and more appropriate for drugs with a longer elimination half-time. Consequently, considerable adjustments in the dosage regimen are recommended.
\end{abstract}

dos age regimen.

Sulfaphenazole, Eftolon ${ }^{\circledR}$, has been approved for veterinary use for many years. The substance has been regarded as a long-acting sulfonamide, and the dosage regimen recommended by the manufacturer reflects this supposition. Some studies, however, report a rather short half-time of sulfaphenazole in ruminants (Luthman \& Jacobsson 1979).

The purpose of the present study was to obtain information about the disposition kinetics of sulfaphenazole in sheep and, if necessary, indicate dosage adjustments.

\section{MATERIAL AND METHODS}

Four clinically healthy 8-10 months old rams of mixed breed (Dala $\times$ Ryggja) were used for the study. The animals were kept indoors and fed concentrates, approximately $0.1 \mathrm{~kg} / \mathrm{day}$, and water and hay ad libitum. 
Each sheep received single doses of $50 \mathrm{mg} / \mathrm{kg}$ sulfaphenazole, as an i.v. bollus injection (Eftolon $\circledast$ inj. $)^{\star}$ and as Eftolon ${ }^{\circledR}$ powder in water by a stomach tube on 2 occasions 2 months apart. Blood samples were drawn in heparinized vacutainers from the jugular vein at pre-determined times. Samples were centrifuged and plasma stored at $-20^{\circ} \mathrm{C}$ until analysis.

Determination of sulfaphenazole was performed by HPLC on a modular system (Waters Assoc., Milford, MA, USA). Plasma proteins were denaturated by mixing $1 \mathrm{ml}$ of sample with $1 \mathrm{ml}$ of acetonitrile. After centrifugation an aliquot of the supernatant was injected into the system. The mobile phase $(1.5 \mathrm{ml} / \mathrm{min})$ was acetonitrile/water, $(40 / 60 \mathrm{v} / \mathrm{v})$ to which was added $0.2 \%$ (vol) triethylamine, and $\mathrm{pH}$ adjusted to 4.2 with orthophosphoric acid. Separation was performed on a Radial-PAK $\mathrm{C}_{18}$ column (10 $\mathrm{cm} \times 8 \mathrm{~mm}$ I.D., $5 \mu \mathrm{m}$ particle size, Waters Assoc.) and peaks monitored at $254 \mathrm{~nm}, 0.02$ absorbance units full scale.

The binding of sulfaphenazole to plasma proteins was determined by equilibrium dialysis at $37^{\circ} \mathrm{C}$ for $3 \mathrm{~h}$ (Pike \& Skuterud 1983). Plasma was dialysed against a Krebs-Ringer bicarbonate buffer ( $1 \mathrm{ml}$ of each) in clamped perspex cells separated by a pre-moistened dialysis membrane( American Cyanamid Co.). $\mathrm{pH}$ was adjusted to 7.35 with $5 \%$ carbon dioxide in oxygen. The buffer was injected directly into the HPLC-system, while plasma was treated as above.

Kinetic parameters were calculated by standard methods (Gibaldi \& Perrier 1975, Baggot 1977).

\section{RESULTS}

The plasma levels of sulfaphenazole, plotted logarithmically against time, are illustrated in Fig. 1. After i.v. injection the curves showed an initial rapid distribution phase ( $\alpha$-phase) and a slower elimination phase ( $\beta$-phase). The kinetic parameters given in Table 1 were therefore calculated by means of an open two compartment model. Gastrointestinal absorption was a slow process compared to distribution, and no distribution phase could be observed on the drug concentration time plot. An open one compartment model was used for calculations. Belgium.

* Preparations were kindly supplied by Pfizer Corp., Brussels, 


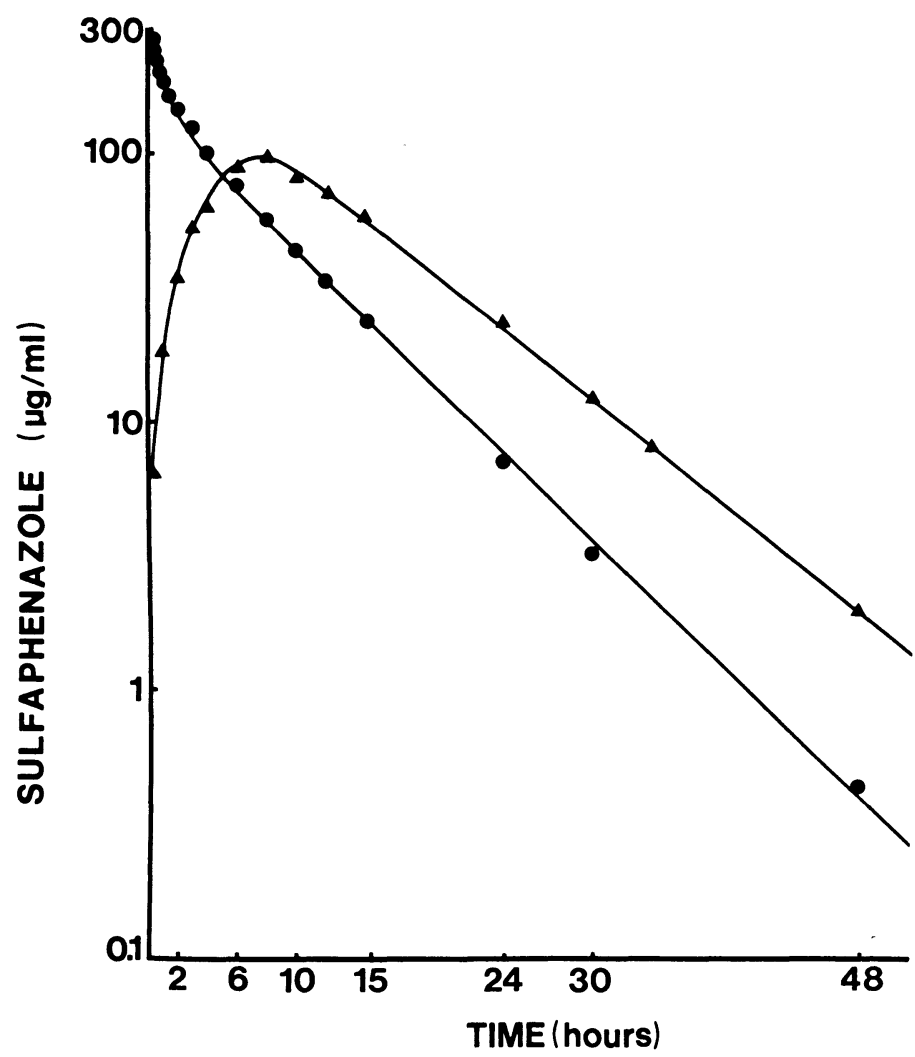

Figure 1. Mean plasma concentrations versus time after intravenous ( $-\mathbf{O})$ and oral $(\boldsymbol{\Delta}-\boldsymbol{\Delta})$ administration of sulfaphenazole (Eftolonß $50 \mathrm{mg} / \mathrm{kg}$ ) to 4 sheep.

After i.v. injection mean distribution half-time was $0.62 \mathrm{~h}$ and elimination half-time $5.58 \mathrm{~h}$ (Table 1 ). The central volume of distribution was $0.169 \mathrm{l} / \mathrm{kg}$ and apparent volume of drug distribution $0.273 \mathrm{l} / \mathrm{kg}$. Total body clearance was $34.1 \mathrm{ml} / \mathrm{kg} / \mathrm{h}$. After oral dosing absorption half-time was $2.66 \mathrm{~h}$ and elimination half-time $7.12 \mathrm{~h}$. Sulfaphenazole was completely absorbed, and the calculated time of peak plasma concentration was somewhat earlier than what could be read from the plot.

The binding of sulfaphenazole to plasma proteins was concentration dependent and ranged from approximately 93.5 to $99 \%$ at total drug concentrations from 130 to $10 \mu \mathrm{g} / \mathrm{ml}$ (Fig. 2). 
T a b l e 1. Estimated pharmacokinetic parameters of sulfaphenazole after intravenous bolus injection and oral administration of proprietary formulations (Eftolon $\circledast$ ) at a dose level of $50 \mathrm{mg} / \mathrm{kg}$ to sheep.

\begin{tabular}{|c|c|c|}
\hline \multirow[t]{2}{*}{ Parameter } & \multicolumn{2}{|c|}{ Mode of administration } \\
\hline & $\begin{array}{c}\text { i.v. } \\
n=4 \\
\text { mean } \pm \text { s.d. }\end{array}$ & $\begin{array}{c}\text { p.o. } \\
\mathrm{n}=4 \\
\text { mean } \pm \mathrm{s.d} .\end{array}$ \\
\hline$t 1 / 2^{\alpha} \alpha \quad h$ & $0.62 \pm 0.21$ & \\
\hline$t_{1 / 2} \beta \quad h$ & $5.58 \pm 0.31$ & \\
\hline$V_{c} \quad l / k g$ & $0.169 \pm 0.010$ & \\
\hline $\mathrm{v}_{\mathrm{d}} \beta \mathrm{l} / \mathrm{kg}$ & $0.273 \pm 0.022$ & \\
\hline $\mathrm{Cl}_{\mathbf{T}} \mathrm{ml} / \mathrm{kg} / \mathrm{h}$ & $34.1 \pm 3.4$ & \\
\hline $1 / 2 \mathrm{a} \quad \mathrm{h}$ & & $2.66 \pm 0.15$ \\
\hline$t_{1} / 2 \mathrm{el} h$ & & $7.12 \pm 0.33$ \\
\hline$t_{\max } h$ & & $6.03 \pm 0.24$ \\
\hline AUC $\mu \mathrm{g} / \mathrm{ml} / \mathrm{h}$ & $1479 \pm 150$ & $1536 \pm 165$ \\
\hline $\mathbf{F}$ & & $1.05 \pm 0.15$ \\
\hline
\end{tabular}

$\mathrm{t}_{1 / 2} \alpha=$ distribution half-time, $\mathrm{t}_{1 / 2} \beta=$ elimination half-time, $\mathrm{V}_{\mathrm{c}}=$ apparent volume of central compartment, $\mathrm{V}_{\mathrm{d}} \beta=$ apparent volume of distribution, $\mathrm{Cl}_{\mathrm{T}}=$ total body clearance, $\mathrm{t} 1 / \mathrm{a} \mathrm{a}=$ absorption half-time, $t_{1 / 2} e l=$ elimination half-time, $t_{\max }=$ time of maximum drug concentration in plasma, $\mathrm{AUC}=$ area under the plasma drug concentration versus time curve, $F=$ fraction of dose which reaches systemic circulation.

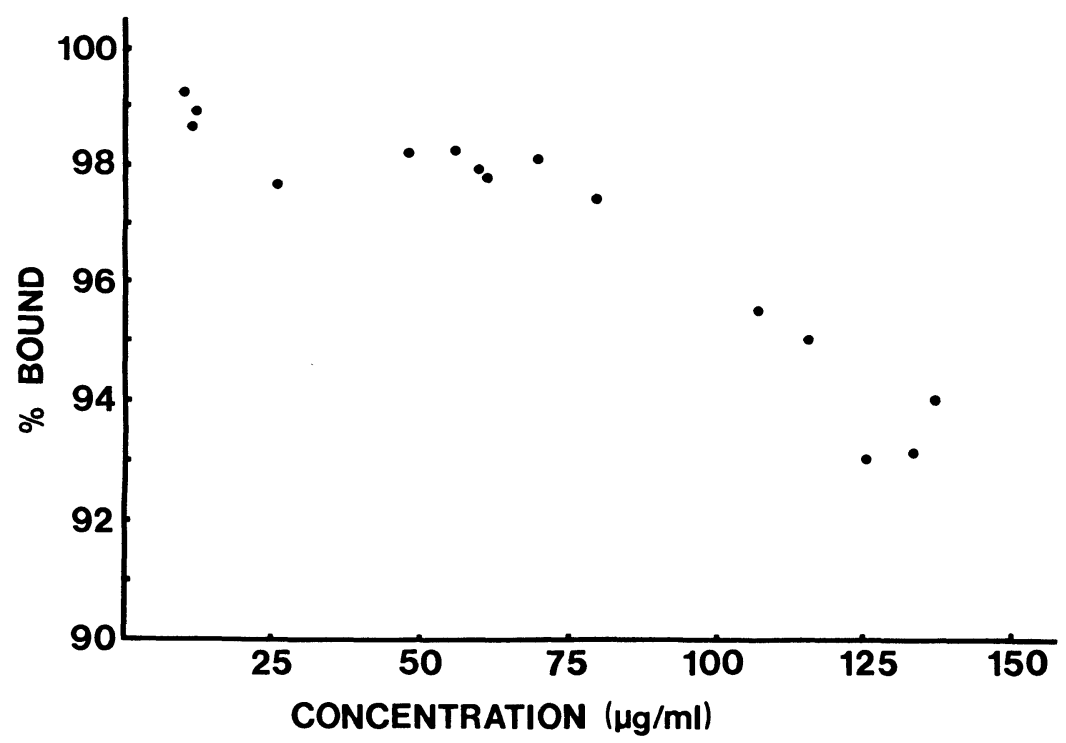

F $\&$ g u re 2. Protein binding of sulfaphenazole related to total concentration in sheep plasma. Each point represents individual samples from several animals. 


\section{DISCUSSION}

The number of animals used in this study is the lowest possible for pharmacokinetic studies, but with the relatively small individual variations the results may be considered reliable.

The steadily increasing number of reports on species differences in the disposition of drugs, highlights the need for pharmacokinetic studies in different species, but such studies of sulfaphenazole in sheep seem to be very scanty.

Like most sulfonamides, the disposition of sulfaphenazole after i.v. injection fitted an open two compartment model. The distribution half-time was relatively short and comparable to many other sulfonamides in the cow (Nielsen \& Rasmussen 1977 ). The rate of absorption after oral administration i.e. $t_{1 / 2} \mathrm{a}=$ $2.66 \mathrm{~h}$, and peak plasma concentration after $6-8 \mathrm{~h}$ in a ruminant, must also be regarded as relatively rapid, and comparable to what was found in the cow (Ødegaard \& Råstad 1986).

The binding to plasma proteins was high, i.e. $93.5-96 \%$ at therapeutic concentrations, compared to approximately $85 \%$ in the cow (Ødegaard \& Råstad 1986). The apparent volume of distribution was $0.273 \mathrm{l} / \mathrm{kg}$. This is very close to the figure for sulfamethoxypyridazine in sheep (Indreb $\varnothing \&$ Ødegaard 1986), somewhat higher than for sulfaphenazole in cows (Ødegaard \& Råstad 1986), and lower than for the majority of sulfonamides examined by Nielsen \& Rasmussen (1977). In the latter study, however, the volumes are somewhat overestimated as they were calculated from dose and zero time intercept obtained by extrapolation of the $\beta$-phase of the plot.

The elimination half-time of $5.58 \mathrm{~h}$ is somewhat shorter than found by Luthman \& Jacobsson (1979), but longer than in cows (Luthman \& Jacobsson 1979, Sobach \& Lamminsivu 1979, Ødegaard \& Råstad 1986). One reason for this difference may be the difference in plasma protein binding and a lower rate of glomerular filtration in the sheep. A metabolite peak, probably the $\mathrm{N}^{4}$-acetylated sulfonamide, was relative to the sulfaphenazole peak, much higher in the cow. This may also indicate a faster metabolism in the cow than in the sheep.

In general plasma concentrations of sulfonamides from 50 to $150 \mu \mathrm{g} / \mathrm{ml}$ are considered therapeutic. Sulfaphenazole is supposed to be one of the more potent sulfonamides. On the other hand, however, binding to plasma proteins is high and the apparent volume of distribution is lower than for the majority 
of sulfonamides. Supposing that a minimum plasma concentration of $50 \mu \mathrm{g} / \mathrm{ml}$ is effective in the treatment of infections caused by susceptible organisms, a maintenance dose may be calculated. At a dosage interval of $12 \mathrm{~h}$, the calculated dose is $47 \mathrm{mg} / \mathrm{kg}$, yielding a mean concentration at the steady state of $116 \mu \mathrm{g} / \mathrm{ml}$. Doubling of the dosage interval will result in a dose of $257 \mathrm{mg} /$ $\mathrm{kg}$ and mean concentration of $316 \mu \mathrm{g} / \mathrm{ml}$. At a dosage interval of $12 \mathrm{~h}$ i.e. approximately 2 elimination half-times of the drug, the ratio between maximum and minimum plasma concentrations is $4 / 1$. These calculations involves the assumption that the drug is given intravenously or is very rapidly absorbed. In oral dosing to ruminants and a relatively slow absorption, the fluctuation in drug plasma concentrations will be less pronounced, but the mean concentration will remain unchanged. Because linear changes in dosage interval cause geometric changes in fluctuation of drug plasma concentration, the dosage interval should not be too long relative to the elimination half-time of a bacteriostatic drug. To reach the steady state from the first dosing interval, a loading dose may be given, the magnitude of which depends on the dosage interval relative to the elimination halftime of the drug.

Provided that a plasma concentration of $50 \mu \mathrm{g} / \mathrm{ml}$ sulfaphenazole is effective, a loading dose of $60 \mathrm{mg} / \mathrm{kg}$ and maintenance doses of $45 \mathrm{mg} / \mathrm{kg}$ two times daily may be recommended in sheep. This is higher than the dosage regimen recommended by the manufacturer $(50-100 \mathrm{mg} / \mathrm{kg}$ initially and $25-50 \mathrm{mg} /$ $\mathrm{kg}$ daily) which wifl, according to calculations as above, at best result in minimum and mean plasma concentrations of approximately 10 and $60 \mu \mathrm{g} / \mathrm{ml}$, respectively.

\section{REFERENCES}

Baggot, J. D.: Principles of Drug Disposition in Farm Animals: The Basis of Veterinary Clinical Pharmacology. W. B. Saunders Company, Philadelphia, USA 1977.

Gibaldi, M. \& D. Perrier: Pharmacokinetics. In J. Swarbrick (ed.), Drugs and the Pharmaceutical Sciences. Vol. 1. Marcel Dekker, New York 1975.

Indreb $\varnothing, A . \& S . A . \emptyset$ degaard: Sulfametoxypyridazin (Longamid®) og sulfanilamid til søye. En farmakokinetisk studie. (Sulfamethoxypyridazine (Longamid $\AA$ ) and sulfanilamide in the ewe. A pharmacokinetic study). Norsk Vet.-tidsskr. 1986, 98, 183-188. 
Luthmann, J. \& S.-O. Jacobsson: Serumkoncentrationer av sulfonamider efter oral och parenteral tillførsel. (Sulfonamide concentrations in blood serum after oral and parenteral administration). Svensk Vet.-Tidn. 1979, 31, 783-787.

Nielsen, P.\&F. Rasmussen: Half-life, apparent volume of distribution and protein-binding for some sulphonamides in cows. Res. Vet. Sci. 1977, 22, 205-208.

Pike, E. \& B. Skuterud: Methodological aspects on the determination of plasma binding of amitriptyline and nortriptyline. Norv. pharm. acta $1983,45,33-42$.

Sobach, S. \& U. Lamminsivu: The effect of protein-binding on the excretion of three sulphonamide preparations in the milk of dairy cows, examined by chemical and microbiological methods. Nord. Vet.-Med. 1979, 31, 309-315.

Ødegaard, S. A. \& A. Råstad: Pharmacokinetics of sulfaphenazole in catte. J. vet. Pharmacol. Therap. 1986, 9, in press.

\section{SAMMENDRAG}

Farmakokinetisk undersøkelse av sulfafenazol hos sau.

Registrerte formuleringer av sulfafenazol (Eftolon $®$ ) ble gitt intraven $\varnothing$ st og oralt til sau. Etter intraven $\varnothing$ s injeksjon kunne konsentrasjonene av sulfonamid i plasma tilpasses en to-kompartment modell. Halveringstiden for eliminasjonen var i gjennomsnitt $5,58 \mathrm{t}$, tilsynelatende distribusjonsvolum $0,273 \mathrm{l} / \mathrm{kg}$, og total clearance $34,1 \mathrm{ml} / \mathrm{kg} / \mathrm{t}$. Bedømt etter arealet under kurvene, ble sulfafenazol fullstendig absorbert etter oral dosering. Konsenstrasjoner i plasma ble beskrevet av en en-kompartment modell med halveringstider for absorpsjon og eliminasjon på henholdsvis 2,66 og 7,12 t. Binding til plasmaproteiner var konsentrasjonsavhengig, og varierte ved terapeutiske konsentrasjoner av sulfafenazol fra 93 til $96 \%$.

Resultatene viser at de doser som angis av produsenten er lave, foruten at doseintervallene passer bedre for farmaka med lengre halveringstid. Det er f $\varnothing$ lgelig anbefalt vesentlige endringer i doseringsregime.

(Received February 7, 1986).

Reprints may be requested from: S. A. Ødegaard, the Department of Pharmacology and Toxicology, Norwegian College of Veterinary Medicine, P. O. Box 8146 Dep., N-0033 Oslo 1, Norway. 